\title{
GURU BERKARAKTER UNTUK PENDIDIKAN KARAKTER DI SEKOLAH
}

\author{
Suci Cahyati \\ Mahasiswa Pascasarjana, Univaersitas Negeri Yogyakarta \\ sucicahyati.2017@student.uny.ac.id
}

\begin{abstract}
ABSTRAK
Pendidikan karakter dipengaruhi oleh peran guru yang berkarakter. Guru merupakan role model yang dijadikan panutan dan contoh nyata bagi peserta didik di sekolah maupun di masyarakat. Namun kenyataan di lapangan menunjukkan tidak semua guru mampu mendidik. Hal ini ditunjukkan dari maraknya kasus anmoral yang dilakukan oleh guru pada peserta didik seperti pelecehan seksual, kekerasan fisik, bullying, merokok di lingkungan sekolah, dan lain sebagainya. Guru yang tidak bermoral bisa menjadi faktor yang mempengaruhi bobroknya moral anak bangsa. Guru seharusnya dalam mendidik karakter haruslah lebih dahulu berkarakter yang baik sehingga dapat memberi contoh pada peserta didik. Ki Hadjar Dewantara menyatakan Ing Ngarsa Sung Tulada, Ing Madya Mangun Karsa, Tut Wuri Handayani. Istilah ini mengindikasikan bahwa guru merupakan contoh yang sangat berpengaruh terhadap pembentukan karakter. Bagaimanakah idealnya seorang guru yang berkarakter merupakan pertanyaan penting yang perlu dijawab oleh semua pendidik. Guru yang memiliki karakter ideal dapat berkontribusi terhadap pendidikan karakter peserta didik.
\end{abstract}

Kata Kunci: guru, karakter, pendidikan.

\begin{abstract}
Character education is influenced by the teacher's character role. The teacher is a role model that is used as a role model and a real example for students in school and in the community. But the reality in the field shows that not all teachers are able to educate. This is shown from the rampant anmoral cases committed by teachers on students such as sexual harassment, physical violence, bullying, smoking in the school environment, and so forth. An immoral teacher can be a factor that affects the moral decline of the nation's children. Teachers should be able to character first in good character so they can set an example for students. Ki Hadjar Dewantara stated Ing Ngarsa Sung Tulada, Ing Madya Mangun Karsa, Tut Wuri Handayani. This term indicates that the teacher is an example that is very influential on the formation of character. How is the character that must be possessed by a teacher is an important question that needs to be answered by all educators. Teachers who have ideal character can contribute to the character education of students.
\end{abstract}

Keyword: teacher, character, education.

\section{PENDAHULUAN}

Selama ini sering dilakukan berbagai penelitian tentang implementasi pendidikan karakter di sekolah. Implementasi yang dilakukan fokus pada pengaruh pembelajaran tertentu untuk karakter tertentu. Pendidikan karakter di sekolah sama halnya seperti mengajarkan tentang karakter. Semua yang disampaikan bersifat teori semata, sementara praktiknya dikesampingkan. Bagaimana hal ini bisa terjadi sementara yang utama dalam pendidikan karakter bukanlah mengajarkannya tetapi mendidikkannya. Dua istilah yang berbeda antara mendidik dan mengajar yang saat ini sering dilupakan oleh guru. 
Mendidik karakter berbeda dengan mengajar karakter. Seorang yang mendidik karakter harus memiliki karakter yang baik terlebih dahulu. Bagaimana seseorang yang tidak bermoral misalnya mengajarkan tentang moral pada orang lain. Secara logika nilai-nilai ini tidak akan sampai dengan baik bahkan menjadi tidak bermakna, hanya sebatas kata-kata saja. Setiap orang bisa memahami tapi tidak semua orang dapat mempraktikkan. Tidak semua orang mampu memberi contoh yang baik, oleh karenanya sebelum memberikan masukan yang baik, seorang harus baik terlebih dahulu. Hadits Abu Hurairah Radhiyallahu anhu bahwa Nabi Shallallahu 'alaihi wa sallam bersabda:

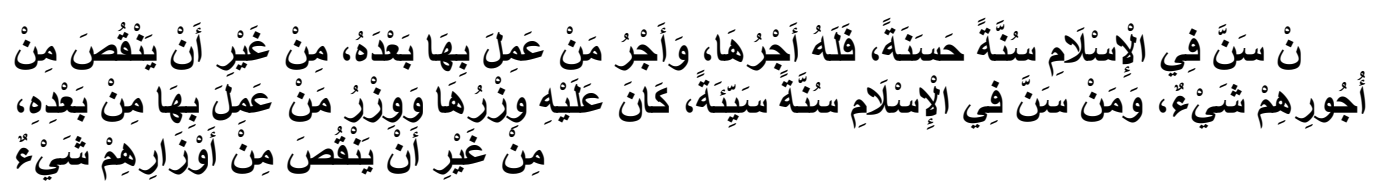

Barangsiapa mencontohkan dalam Islam suatu contoh yang baik, maka ia akan mendapatkan pahalanya, dan pahala orang yang melakukannya setelahnya; tanpa berkurang sesuatu apapun dari pahala mereka. Dan barangsiapa yang mencontohkan dalam Islam suatu contoh yang buruk, maka ia menanggung dosanya dan dosa orang yang mengerjakannya setelah dia, tanpa berkurang sesuatu pun dari dosa-dosa mereka.[HR. Muslim, no. 1017]

Contoh baik dan buruk dibahas dalam hadits tersebut menunjukkan bahwa contoh atau suri tauladan lebih penting dari sekedar teori. Guru harus memberi contoh sehingga dapat menjadi model bagi peserta didik di sekolah. Menurut Noddings dalam Nucci \& Narvaez (2008, 161-174) menyatakan "If we would teach the young to be moral persons, we must demonstrate moral behavior for them. From the care perspective, we must show what it means to care." Hal ini berarti dalam mengajarkan seseorang untuk bermoral, guru harus lebih dulu mencontohkan atau menunjukkan kebiasaan bermoral pada siswa. Dalam perspektiv moral misalnya guru harus menunjukkan makna dari peduli melalui tindakan dan perbuatannya.

Hal ini sejalan dengan istilah "Sebelum melihat keluar, lihatlah ke dalam." Sebelum mengajarkan karakter seorang guru harus memiliki karakter lebih dahulu. Istilah ini merupakan istilah yang tepat untuk mengambarkan bagaimana keadaan dunia pendidikan saat ini. Presiden Jokowi selama kepemimpinannya selalu mengingatkan tentang revolusi mental. Revolusi mental menurut Kristiawan (2015: 13-26) memiliki peran dalam memajukan peradaban manusia. Revolusi mental akan membuat siswa mempunyai kepandaian yang meningkat dan mempunyai adab serta perilaku yang baik. Revolusi mental (Indriyanto, 2014: 554-567) mengkaji revolusi mental dalam konteks pendidikan yang mana karakter manusia dibentuk melalui perilaku. Revolusi mental yang ada pada 
manusia akan berkaitan dengan perilaku, karakter, kebiasaan sepanjang hidupnya dalam bidang apapun termasuk dalam pendidikan dan pengajaran.

Revolusi mental ini berkaitan dengan karakter yang perlu ditekankan dalam pendidikan. Pendidikan merupakan ujung tombak peradaban. Dengan gerakan revolusi mental ini harapannya dapat merubah kondisi masyarakat yang sedang krisis mental menjadi berkarakter. Namun bagaimana jika tombak peradaban itu sendiri tidak berkarakter. Seorang guru mengajarkan pada peserta didik bahwa merokok tidak baik untuk kesehatan, namun setelahnya guru itu merokok baik di dalam maupun di luar lingkungan sekolah. Bagaimana mendidik karakter yang baik jika gurunya sendiri tidak mampu membiasakan diri dan berkarakter baik. Pendidikan merupakan salah satu sarana strategis untuk menjadikan pembentukan karakter peserta didik, untuk itu guru harus memiliki karakter yang baik pula.

Seorang guru yang berkarakter dapat menjadi suri tauladan bagi peserta didiknya. Lembaga Pendidikan Tenaga Kependidikan (LPTK) yang selama ini mencetak calon guru/ tenaga pendidik atau tenaga kependidikan yang diharapkan berkarakter serta memiliki tauladan serta bisa mendidik karakter kepada peserta didiknya. Menjadi guru yang bisa menjadi suri tauladan memang tidak mudah, masih ada guru yang hanya bisa mengajarkan ilmu dan ketrampilan namun belum bisa menjadi suri tauladan yang bisa ditiru oleh peserta didiknya, ibarat kata guru kencing berdiri murid kencing berlari. Seorang guru yang berperilaku yang tidak baik dihadapan peserta didik maka mudahlah peserta didik tersebut meniru perilaku yang kurang baik bahkan jauh lebih buruk, namun satu suri tauladan yang baik dari guru akan mengajarkan makna pendidikan karakter yang mendalam dan dapat ditiru oleh peserta didik dengan baik pula melebihi perkataan atau ucapan seorang guru. Jadi satu suri tauladan lebih baik dari seribu ucapan.

Peserta didik merindukan sosok seorang guru yang berakhlak mulia, berjiwa besar serta bisa menjadi suri tauladan yang mampu menghargai dan mendidiknya dengan kasih sayang dengan sepenuh hati layaknya anak sendiri. Guru yang ideal seperti apa yang bisa dirindukan peserta didiknya supaya bisa mengantarkan ke gerbang kesuksesan serta menjadi dambaan peserta didik dalam membentuk karakter, mendapatkan ilmu pengetahuan dan ketrampilan hidup (life skill). Guru yang bisa memberikan suri taulan kepada peserta didiklah yang memberikan dukungan terbesar dalam pembentukan karakter dan kepribadian peserta didik di sekolah dan masyarakat.

Pentingnya karakter bagi seorang guru akan berdampak positif bagi tumbuh kembangnya peserta didik. Karakter menurut Gunawan (2012) adalah bawaan, hati, jiwa, 
kepribadian, budi pekerti, perilaku, personalitas, sifat, tabiat, temperamen, watak. Karakter yang terbentuk pada seseorang mengacu kepada serangkaian sikap, perilaku, motivasi dan keterampilan. Sedangkan menurut John Sewey dalam Gunawan (2012) merupakan hal yang lumrah dalam teori pendidikan bahwa pembentukan watak (karakter) memiliki arah tujuan umum pengajaran dan pendidikan budi pekerti di sekolah. Kekuatan karakter yang ada akan terbentuk dengan alami apabila ada semangat dan dorongan dari lingkungan sekitar. Peran keluarga, sekolah, dan masyarakat sangat berperan penting dalam upaya dan usaha yang sadar dan terarah dalam mencetak kekuatan karakter.

Karakter yang timbul dan ada selama ini tidak bisa diwariskan kepada siapa saja dan kapan saja, karakter harus dibangun, dipupuk dibiasakan secara sadar waktu demi waktu melalui suatu proses yang cukup membutuhkan waktu yang tidak sedikit. Karakter tidak merupakan pemberian sejak lahir yang dimiliki manusia. Setiap manusia memiliki tanggungjawab atas tingkah laku baik itu watak ataupun karakternya. Manusia memiliki kewajiban mengontrol karakternya, dengan tidak menyalahkan orang lain atas perbuatan yang kita lakukan secara sadar baik benar atau salah, karena itu manusia bertanggung jawab atas apa yang terjadi pada dirinya secara penuh. Mengembangkan karakter adalah usaha kita dalam tanggung jawab menjalani kehidupan ini sebagai manusia yang mulia dan berkarakter.

Karakter yang baik menurut Sudrajat (2011) berkaitan dengan mengetahui yang baik (knowing the good), mencintai yang baik (loving the good), dan melakukan yang baik (acting the good). Ketiga hal tersebut sangat berkaitan dan berkesinambungan. Kebiasaan melihat dan melakukan yang baik akan membentuk karakter seseorang. Guru yang memiliki kebiasaan untuk mengetahui yang baik dan bermanfaat baik itu bagi dirinya dan orang lain akan membentuk karakter pribadi yang mulia. Guru yang selalu menyukai dan mencintai yang baik akan terbiasa untuk melakukan hal-hal yang positif. Guru yang selalu melakukan kegiatan yang baik akan membentuk karakter kepribadian yang baik pula. Karakter tersebut apabila dilakukan secara bersama dan dilanjutkan secara berkesinambungan akan mendukung kepribadian dan karakter seorang guru menjadi semakin kuat serta bisa menguatkan kepribadian dalam kehidupannya sehari-hari.

Karakter dalam kurikulum 2013 diatur dalam Permendikbud nomor 20 tahun 2018 tentang penguatan karakter pada satuan pendidikan formal, dinyatakan sebagai berikut:

"Penguatan Pendidikan karakter (PPK) adalah gerakan pendidikan di bawah tanggung jawab satuan pendidikan untuk memperkuat karakter peserta didik melalui harmonisasi olah hati, olah rasa, olah pikir, dan olah raga dengan pelibatan 
dan kerjasama antara satuan pendidikan, keluarga, dan masyarakat sebagai bagian dari Gerakan Nasional Revolusi Mental (GNRM).”

Dalam lingkungan pendidikan, setiap guru berkewajiban untuk mengembangkan karakter peserta didik melalui penguatan karakter meliputi olah rasa, olah hati, olah pikir, dan olah raga dengan melibatkan beberapa unsur satuan pendidikan di lingkungan sekolah meliputi satuan pendidikan, keluarga dan masyarakat, semua saling bersinergi. Karakter akan terbentuk melalui pembiasaan dan berkelanjutan dan berjalan secara harmoni. Dalam hal ini diharapkan guru memperkuat karakter peserta didik terlebih dahulu mempunyai karakter yang baik dan mulia.

\section{METODE PENELITIAN}

Metode yang digunakan dalam penelitian ini adalah menggunakan penelitian deskriptif kualitatif. Menurut Sugiyono (2017 : 2) yang dimaksud dengan metode penelitian adalah metode penelitian pada dasarnya merupakan cara ilmiah untuk mendapatkan data dengan tujuan dan kegunaan tertentu. Penelitian kualitatif deskriptif ini adalah penelitian yang dilakukan dengan cara mendeskripsikan sesuatu pembahasan atau pemecahan masalah dengan menggunakan analisis. Penelitian ini dengan menggunakan kajian literatur review yaitu menguraikan tentang teori, temuan serta penelitian yang lain sebagai acuan dalam penelitian. Dilakukan penelusuran pustaka melalui langkah-langkah mengabungkan informasi yang sesuai dengan penelitian. Dalam penyusunan literatur review ini dengan cara mengidentifikasi secara sistematis, penemuan, dan analisis dokumen dokumen yang ada dengan masalah dalam penelitian serta menyusun kerangka pemecahan masalah.

\section{HASIL PENELITIAN DAN PEMBAHASAN Proses Pembentukan Karakter}

Pembentukan karakter seseorang adalah melalui proses yang lama dan di mana proses itu perlu dilalui supaya karakter tersebut terbentuk. Pembentukan karakter yang terbaik adalah dilakukan sejak dini bahkan mulai dalam lingkungan keluarga. Keluarga yang mengenalkan karakter dengan memberikan pengenalan hal-hal yang baik dan positif kepada anak dengan menanamkan sesuatu yang baik supaya tertanam pada diri anak. Selanjutkan pembentukan karakter dengan pemahaman agar bisa dimengerti dan diketahui dan bisa diterapkan dalam kehidupan sehari-hari baik dalam keluarga, sekolah atau masyarakat. Dalam proses penerapan supaya ketika seseorang paham dan bisa diterapkan dalam kegiatannya dan kehidupannya. Ketika seseorang sudah bisa menerapkan karakter tersebut maka diusahakan dilakukan pengulangan atau pembiasaan agar karakter itu 
menjadi kebiasaan yang baik. Setelah kebiasaan yang baik dilakukan proses pembentukan karakter adalah pembudayaan supaya karakter bisa menjadi budaya yang bisa selalu dilakukan. Pembudayaan karakter ini adalah proses yang paling berat yang bisa dilakukan seseorang dalam kesehariannya, namun bila proses pembudayaan sudah bisa diterapkan dalam kehidupan seseorang maka proses selanjutnya adalah proses yang terakhir yaitu internalisasi menjadi karakter yang melekat pada diri seseorang yang merupakan kesadaran seseorang terhadap karakter tersebut tanpa adanya paksaan ataupun dorongan dari luar.

\section{Tahapan Pembentukan Karakter}

Pendidikan karakter dibangun dari sebuah peradaban serta situai perkembangan psikologi manusianya sendiri. Dewantara (1997: 407-410) menyatakan bahwa terdapat hubungan jiwa kebatinan dengan karakter manusia itu. Karakter merupakan perpaduan karakter manusia serta tabiatnya yang bersifat tetap yang menjadi tanda khusus membedakan manusia satu dengan yang lainnya melalui jiwa, raga juga kemauan yang meliputi cipta rasa serta karsa. Karakter yang terbangun melalui nilai yang berasal dari agama serta ideologi ataupun melalui Pendidikan. Nilai yang ada akan membentuk pola pokie seseorang secara menyeluruh dengan menyusun rumusan visi hidup. Visi yang ada diturunkan ke hati membentuk jiwa sanubi seseorang yang akan membentuk suasana kebatinan seseorang dan memasuki raga atau fisik seseorang yang melahirkan tindakan ataupun perbuatan yang disebut sebuah sikap seseorang. Selanjutnya sikap-sikap yang ada pada diri manusia akan memberikan gambaran seseorang atau citra diri seseorang melalui karateristiknya yang disebut karakter.

\section{Guru Berkarakter}

Kusumawati \& Ari Bowo (2019) menyatakan bahwa menjadi guru tidaklah gampang namun perlu waktu, kesabaran, dan keterampilan untuk mendampingi peserta didik. Kusumawati \& Cahyati (2019) menyatakan pembentukan karakter bisa terjadi ketika seseorang melakukan usaha sadar dalam setiap aktivitas kesehariannya dalam menjalani aktivitas sesuai dengan hak dan kewajibannya. Karakter yang baik harus dimiliki oleh seseorang terutama oleh seorang guru yang mendidik dan mengajarkan ilmu dan pengetahuan di sekolah serta tidak hanya di sekolah saja namun bisa di masyarakat pada umumnya. Peran guru menurut Kusumawati (2017:139-148) menjadi penting dalam pembelajaran karakter berbasis Pendidikan. Seorang guru yang berkarakter akan bisa menjadi panutan manusia sekitarnya terutama peserta didiknya, baik itu ucapan, perbuatan atau tindakannya kesehariannya baik di lingkungan sekolah ataupun dalam masyarakat. Seperti halnya pendidikan yang diajarkan oleh Ki Hajar Dewantara yang mengajarkan 
semboyan yang berbunyi Ing Ngarso Sung Tuladha, Ing Madya Mangun Karsa, Tut Wurihandayani. Seorang guru yang berkarakter harus memiliki nilai Ing Ngarso Sung Tuladha yang berarti bahwa seorang guru ketika di depan peserta didik harus bisa memberikan suri tauladan kepada peserta didiknya mulai dari sikap, perkataan serta perbuatannya. Guru berkarakter menurut Kusumawati\& Zuchdi (2019: 63-75) merupakan guru konstruktivitis yang dapat membangun minat dan tujuan anak dalam membangun penalaran anak, eksperimen anak serta memberikan dorongan anak agar bisa bekerjasama antar semua anggota kelas

Seorang guru harus bisa memberikan semangat kepada peserta didik supaya peserta didik mau berbuat hal-hal yang baik dan positif. Seorang guru harus mampu memberikan dorongan kepada peserta didik agar supaya peserta didik tahu apa yang akan dilakukan, sadar akan apa yang dilakukan dan termotivasi melakukan tindakan serta perbuatan yang baik. Guru bisa disebut sebagai seorang pendidik yang memberikan pendidikan kepada peserta didik melalui memberikan pendidikan ilmu pengetahuan juga keterampilan. Pengertian pendidik menurut UU No 20 tahun 2003 tentang Sistem Pendidikan Nasional pasal 39 ayat 2 menyebutkan:

"Pendidik merupakan tenaga profesional yang bertugas merencanakan dan melaksanakan proses pembelajaran, menilai hasil pembelajaran, melakukan pembimbingan dan pelatihan, serta melakukan penelitian dan pengabdian kepada masyarakat, terutama bagi pendidik pada perguruan tinggi".

Sedangkan pengertian guru itu sendiri adalah seperti yang terdapat dalam UU No. 14 tahun 2005 tentang Guru dan Dosen pada pasal 1 ayat 1 yang berbunyi sebagai berikut:

"Guru adalah pendidik profesional dengan tugas utama mendidik, mengajar, membimbing, mengarahkan, melatih, menilai, dan mengevaluasi peserta didik pada pendidikan anak usia dini jalur pendidikan formal, pendidikan dasar, dan pendidikan menengah".

Dalam melaksanakan tugasnya sebagai pendidik seorang guru dituntut menjalankan tugas dengan professional tersebut dengan sepenuh hatinya dan di setiap tindakan dan perbuatan yang dilakukan guru harus bisa mencerminkan guru yang berkarakter mulai dari merencanakan pembelajaran, dalam setiap proses pembelajaran di kelas, dalam melakukan penilaian hasil belajar siswa, guru dalam mendampingi siswa melakukannya dengan penuh kesabaran, ketelitian, yang termasuk bagian nilai dari karakter seorang guru.

\section{Kode Etik Guru}

Sebagai seorang guru tentunya guru mempunyai beberapa kode etik guru dalam mengemban tugas sebagai guru agar dapat melaksanakan tugas dan fungsinya dengan baik 
dan professional. Dalam melaksanakan tugas profesinya guru Indonesia menyadari sepenuhnya bahwa perlu ditetapkan Kode Etik Guru Indonesia sebagai pedoman bersikap dan berperilaku yang mengejewantah dalam bentuk nilai-nilai moral dan etika dalam jabatan guru sebagai pendidik putera-puteri bangsa. Kode etik guru ini berlaku bagi setiap guru Indonesia di manapun guru itu bekerja, mengabdi ataupun sedang melakukan kegiatan pendidikan, pelatihan, penelitian ataupun pengabdian.

Kode etik guru di Indonesia diatur dalam UU No.14 Tahun 2005 tentang Guru dan Dosen pada pasal 1 yang berbunyi sebagi berikut:

"Kode Etik Guru Indonesia adalah norma dan asas yang disepakati dan diterima oleh guru-guru Indonesia. Sebagai pedoman sikap dan perilaku dalam melaksanakan tugas profesi sebagai pendidik, anggota maasyarakat dan warga negara."

Pedoman ini dipakai oleh setiap guru Indonesia dalam rangka melaksanakan tugas dan fungsinya sebagai pengajar dan pendidik. Ada 9 kode etik guru yang dipakai dalam UU No.14 Tahun 2005 tentang Guru dan Dosen sebagai berikut:

1. Guru berbakti membimbing anak didik seutuhnya untuk membentuk manusia pembangunan yang ber-Pancasila.

2. Guru memiliki kejujuran profesional dalam menerapkan kurikulum sesuai dengan kebutuhan anak didik masing-masing.

3. Guru mengadakan komunikasi terutama dalam memperoleh informasi tentang anak didik, tetapi menghindari diri dari segala bentuk penyalahgunaan.

4. Guru menciptakan suasana kehidupan sekolah dan memelihara hubungan dengan orang tua murid sebaik-baiknya bagi kepentingan anak didik.

5. Guru memelihara hubungan baik dengan masyarakat di sekitar sekolahnya maupun masyarakat yang lebih luas untuk kepentingan pendidikan.

6. Guru secara sendiri-sendiri dan atau bersama-sama berusaha mengembangkan dan meningkatkan mutu profesinya.

7. Guru menciptakan dan memelihara hubungan antara sesama guru baik berdasarkan lingkungan kerja maupun di dalam hubungan keseluruhan.

8. Guru secara bersama-sama memelihara, membina dan meningkatkan mutu organisasi guru profesional sebagai sarana pengabdiannya.

9. Guru melaksanakan segala ketentuan yang merupakan kebijakan pemerintah dalam bidang pendidikan.

Dijelaskan bahwa 9 kode etik guru yang terdapat pada UU tersebut menyatakan bahwa seorang guru berkarakter melaksanakan semua kode etik yang ada yaitu guru harus bisa membimbing siswa dengan penuh kasih sayang, guru harus memiliki kejujuran professional, guru harus mampu berkomunikasi dengan baik, guru dapat menjaga keharmonisan suasana kehidupan sekolah dan masyarakat untuk kepentingan sekolah, guru dapat mengembangkan mutu profesinya dengan pelatihan dan mengikuti workshop untuk peningkatan kompetensinya, guru harus bisa menjalin hubungan baik dengan lingkungan 
sekolah, orang tua wali murid dan juga masyarakat, guru meningkatkan mutu organisasi guru professional dan guru bisa melaksanakan segala peraturan dari kebijakan pemerintah dalam Pendidikan.

\section{Kompentensi guru}

Seoorang guru berkarakter harus memiliki kompetensi yang harus dimilikinya dalam pengembangan profesionalnya seorang guru. Kompetensi guru meliputi kompetensi pedagogik, kompetensi kepribadian, kompetensi sosial, dan kompetensi profesional yang diperoleh melalui pendidikan profesi seperti yang dituangkan dalam Undang-Undang Nomor 14 Tahun 2005 tentang Guru dan Dosen. Standar Kompetensi Guru adalah beberapa indikator yang dapat dijadikan ukuran karakteristik guru yang dinilai kompeten secara profesional. Kompetensi guru merupakan perpaduan antara kemampuan personal, keilmuan, teknologi, sosial, dan spiritual yang secara menyeluruh membentuk kompetensi standar profesi guru, yang mencakup penguasaan materi, pemahaman terhadap peserta didik, pembelajaran yang mendidik, pengembangan pribadi, dan profesionalisme.

Kompetensi guru yang dimaksud adalah sebagai berikut:

\section{Kompetensi Pedagogik}

Kompetensi yang meski dimiliki seorang guru adalah bahwa guru harus bisa mengelola pembelajaran peserta didik. Guru dituntut harus mengetahui rekam jejak dan karakteristik peserta didiknya dan memiliki kemampuan untuk mendampingi peserta didik baik secara klasikal ataupun individual, karena siswa adalah unik dan masing-masing siswa memiliki gaya belajar masing masing.

\section{Kompetensi Kepribadian}

Kompetensi kepribadian adalah kemampuan kepribadian yang mantap, berakhlak mulia, arif, dan berwibawa serta menjadi teladan peserta didik. Kompetensi kepribadian merupakan kemampuan personal yang mencerminkan kepribadian yang mantap, stabil, dewasa, arif, dan berwibawa, menjadi teladan bagi peserta didik, dan berakhlak mulia. Guru yang berkarakter yang bisa menunjukkan jatidirinya dalam mendampingi siswa dan menjadi suri tauladan siswa atau peserta didiknya dalam setiap ucapan, tindakan serta perbuatanya. Sifat peserta didik yang suka meniru akan mengikuti bagaimana karakter guru melalui kepribadian yang dipunyai seorang guru baik dalam kelas ataupun dalam masyarakat.

\section{Kompetensi Sosial}

Kompetensi sosial adalah kemampuan guru untuk berkomunikasi dan berinteraksi secara efektif dan efisien dengan peserta didik, sesama guru, orangtua/wali peserta 
didik, dan masyarakat sekitar. Guru yang berkarakter bisa menjadi penghubung antara murid dengan orang tua ataupun dengan masyarakat. Dengan tutur kata dan Bahasa yang baik akan membudahkan berkomunikasi yang baik agar tujuan pembelajaran tercapai seperti yang diharapkan.

\section{Kompetensi Profesional}

Kompetensi profesional adalah kemampuan penguasaan materi pelajaran secara luas dan mendalam. Guru berkarakter akan mampu melakukan pengembangan diri melalui diskusi dengan rekan kerja, atasan, organisasi profesi serta mengikuti pelatihan-pelatihan dan workshop supaya terdapat peningkatan ilmu pengetahuan serta ketrampilan yang semestinya dimiliki oleh guru agar menjadi guru yang berkarakter dan professional.

\section{Guru Berkarakter dalam Pendidikan Moral}

Menurut Lickona (2013), karakter berkaitan dengan konsep moral (moral knonwing), sikap moral (moral felling), dan perilaku moral (moral behavior). Pendidikan karakter menurut Dirsa \& Kusumawati (2019: 159) atau pendidikan moral adalah proses yang berkelanjutan, tujuan yang ingin dicapai oleh pendidikan karakter adalah penerapan nilainilai keteladanan yang dibentuk pada setiap pribadi manusia sebagai makhluk social akan tersampaikan dengan tepat sasaran. Pendidikan moral yang bisa disampaikan guru melalui tindakan langsung yang bisa dipraktikkan oleh peserta didik baik perkataan, perbuatan atau perilaku. Dan yang terakhir dalam mewujudkan tercapainya Pendidikan moral ke siswa atau peserta didik diperlukan sebuah konfirmasi melalui diskusi atau konfirmasi dengan pihak keluarga, teman sebaya bahkan pada masyarakat akan semuanya terdapat keselarasan atau sinergitas dalam pencapaian tujuan pendidikan moral, yaitu peserta didik menjadi pribadi yang mandiri, cerdas, santun, sopan dan berkarakter serta pendidikan yang ada dilakukan secara humanis, dengan memperlakukan siswa sebagai manusia yang mempunyai hati nurani

Dalam Nucci \& Narvaez (Noddings, 2008: 168) dalam penjelasanya tentang model dalam pendidikan moral, dapat dilakukan melalui empat komponen yaitu: modeling, dialouge, practice, dan confirmation. Seorang guru berkarakter harus bisa menjadi model dalam setiap tindakan serta perilakunya dalam mendidik moral kepada peserta didiknya. Peserta didik akan tahu, melihat, mendengar bagaimana sikap dari tindakan gurunya dalam memberikan pengajaran dan bimbingan. Peserta didik mendapatkan figure dari gurunya dan bisa meniru atau melakukan tindakan yang baik dan positif untuk dilakukan. Dalam 
penyampaian Pendidikan moral kepada peserta didik juga diperlukan sebuah dialog yang sederhana dan komunikatif, saling terbuka serta jujur supaya

\section{SIMPULAN}

Guru merupakan jendela pengetahuan yang berfungsi sebagai jembatan bagi siswa dalam memperoleh ilmu dan contoh dalam berperilaku. Guru bisa menunjukkan jalan yang benar pada peserta didik dalam membimbing siswa menjadi manusia yang berkarakter. Guru harus memiliki kemampuan mendidik diri sendiri melalui aktivitasnya dalam mendidik peserta didik. Guru yang berkarakter adalah guru yang memiliki pribadi yang baik dan menjadi suri tauladan peserta didiknya melalui dialog atau komunikasi yang terjalin baik, terbuka dan saling mengerti baik guru ataupun siswanya. Guru yang berkarakter akan memiliki hati yang luas dan terbuka serta sabar mendengarkan keluh kesah siswa, curhatan siswa ataupun pendapat siswa. Guru yang berkarakter jujur terbuka adalah guru yang bisa menyelami siswanya satu persatu yang memiliki karakter serta kebutuhan yang berbeda-beda, mau mendengarkan dan menjadi teman yang baik bagi siswanya menjadi dambaan siswa atau peserta didik. Guru yang memiliki karakter ideal dapat berkontribusi terhadap pendidikan karakter peserta didik.

\section{SARAN}

Artikel ini hanya terbatas pada kajian teori tentang guru berkarakter yang ideal. Rekomendasi selanjutnya dapat dilakukan dengan membahas lebih dalam mengenai guru, karakter guru dan bagaimana penerapan dan pelaksanaan pendidikan moral di sekolah, keluarga dan masyarakat. Perlu dilakukan penelitian terkait implementasi pendidikan karakter berbasis kompetensi dan keprofesionalan guru.

\section{DAFTAR PUSTAKA}

Dewantoro, Ki Hajar. (1977). Pendidikan, Cetakan Kedua. Majelis Luhur Persatuan Taman Siswa Yogyakarta.

Dirsa, A., \& Kusumawati, I. (2019). Implementasi Pemikiran Imam Al-Ghazali tentang Pendidikan Karakter. Academy of Education Journal, 10(02), 159-169.

Gunawan, H. (2012). Pendidikan Karakter. Bandung: Alfabeta, 2.

Indriyanto, B. (2014). Mengkaji Revolusi Mental dalam Konteks Pendidikan. Jurnal

Pendidikan dan Kebudayaan, 20(4), 554-567.

Izzan, A. (2012). Membangun guru berkarakter. Humaniora. 
Kristiawan, M. (2016). Telaah Revolusi Mental Dan Pendidikan Karakter Dalam Pembentukkan Sumber Daya Manusia Indonesia Yang Pandai Dan Berakhlak Mulia. Ta'dib, 18(1), 13-25.

Kusumawati, I. (2017). Pengembangan Karakter Siswa Raudlatul Athfal Berbasis Pendidikan Agama Islam. aṣ-șibyān: Jurnal Pendidikan Anak Usia Dini, 1(02), 139148.

Kusumawati, I., \& Cahyati, S. (2019). Peran Wanita Dalam Pembentukan Karakter Di Bidang Olahraga.

Kusumawati, I., \& Zuchdi, D. (2019). Pendidikan Moral Anak Usia Dini Melalui Pendekatan Konstruktivis. Academy of Education Journal, 10(01), 63-75.

Kusumawati, I, \& Ari Bowo, A. (2019). Prosiding Conferensi Nasional Kewarganegaraan IV: Penguatan Pancasila \& Kewarganegaraan Dalam Memperkukuh Jati Diri Bangsa Di Era Distrupsi. Yogyakarta. UNY Press.

Lickona, Thomas. (2013). Pendidikan Karakter: Panduan Lengkap Mendidik Siswa Menjadi Pintar dan Baik. Bandung: Penerbit Nusa Media

Nucci, LarryP. \& Narvaez, Darcia. Eds. 2008. Handbook of moral and character education. New York and London: Routledge Taylon \& Francis Group.

Permendikbud nomor 20 tahun 2018 tentang Penguatan Karakter pada Satuan Pendidikan Formal.

Sudrajat, A. (2011). Mengapa Pendidikan Karakter?, Jurnal Pendidikan Karakter, 1(1).

Sugiyono. (2017). Metode Penelitian Kuantitatif, Kualitatif, dan R\&D. Bandung : Alfabeta, CV.

Undang-Undang No 20 tahun 2003 tentang Sistem Pendidikan Nasional.

Undang-Undang No. 14 tahun 2005 tentang Guru dan Dosen. 